\title{
Transfer of the Type Species of the Genus Thermobacteroides to the Genus Thermoanaerobacter as Thermoanaerobacter acetoethylicus (Ben-Bassat and Zeikus 1981) comb. nov., Description of Coprothermobacter gen. nov., and Reclassification of Thermobacteroides proteolyticus as Coprothermobacter proteolyticus (Ollivier et al. 1985) comb. nov.
}

\author{
FRED A. RAINEY AND ERKO STACKEBRANDT* \\ DSM-Deutsche Sammlung von Mikroorganismen und Zellkulturen, \\ Mascheroder Weg 1b, 38124 Braunschweig, Germany
}

\begin{abstract}
Phylogenetic and phenotypic evidence demonstrates the taxonomic heterogeneity of the genus Thermobacteroides and indicates a close relationship between Thermobacteroides acetoethylicus and members of the genus Thermoanaerobacter. Since $T$. acetoethylicus is the type species of Thermobacteroides, its removal invalidates the genus. As a consequence, the remaining species Thermobacteroides proteolyticus is proposed as the type species of the new genus Coprothermobacter gen. nov., as Coprothermobacter proteolyticus comb. nov.
\end{abstract}

Recent phylogenetic studies $(8,9)$ of anaerobic thermophilic species demonstrated that the majority of strains fall within the phylogenetic confines of the Clostridium-Bacillus subphylum of gram-positive bacteria. In contrast to the phylogenetically coherent genera Thermoanaerobacter (6) and Thermoanaerobacterium (6), members of Thermobacteroides $(1,7)$ belonged to phylogenetically very diverse taxa (8). While the type species Thermobacteroides acetoethylicus (1) was closely related to members of Thermoanaerobacter (9), Thermobacteroides proteolyticus represented a deep root adjacent to members of the order Thermotogales, showing only $81.9 \%$ sequence similarity with Thermobacteroides acetoethylicus over the stretch of about 1,200 analyzed nucleotides (8). On the basis of these phylogenetic findings, supported by phenotypic characteristics, we put forward the evidence for the reclassification of the species investigated. The genus Thermobacteroides contains three validly described species, Thermobacteroides acetoethylicus $(1,9)$, Thermobacteroides proteolyticus (7), and Thermobacteroides leptospartum $(4,12)$. Attempts to obtain Thermobacteroides leptospartum IAM 13499 from the Institute of Applied Microbiology, University of Tokyo, Tokyo, Japan, failed.

This article is composed of two parts: (i) the transfer of the type species of Thermobacteroides, Thermobacteroides acetoethylicus, to the genus Thermoanaerobacter, with the consequence of invalidating the genus Thermobacteroides, and (ii) the description of the genus Coprothermobacter and the assignment of Thermobacteroides proteolyticus as the type species Coprothermobacter proteolyticus.

Thermoanaerobacter acetoethylicus comb. nov. Genera Thermobacteroides and Thermoanaerobacter were both described in $1981(1,13)$, and the type strain of each was not available to the authors of the article on the other genus for direct comparison. It was not until recently that the close phylogenetic relatedness of the type strains of the type species of these two genera was demonstrated (9). Thermobacteroides acetoethylicus was never included in DNA

\footnotetext{
${ }^{*}$ Corresponding author.
}

hybridization studies with all members of Thermoanaerobacter $(6,10)$ despite the fact that, like Thermoanaerobacter species, Thermobacteroides acetoethylicus is an anaerobic, thermophilic, glycolytic bacterium capable of growth above $70^{\circ} \mathrm{C}$ that has been isolated from geothermal environments. The reclassifications of the recent study of Lee et al. (6) increased the numbers of species of Thermoanaerobacter to now include Thermoanaerobacter ethanolicus, Thermoanaerobacter brockii, Thermoanaerobacter finnii, and Thermoanaerobacter thermohydrosulfuricus. Thermobacteroides acetoethylicus seems to have been overlooked in recent studies, possibly because of the differences previously reported to exist between Thermobacteroides acetoethylicus and Thermoanaerobacter brockii (1) in motility, Gram staining, fermentation end products, cell wall structure, and (detected later) spore formation (2). These organisms share as one of the main features used to define members of Thermoanaerobacter the reduction of thiosulfate, but not sulfate, to sulfide $(1,5)$. Other common features (for which data are available) are rod-shaped morphology of organisms from the logarithmic phase of growth, DNA base composition of 31 to $37 \mathrm{~mol} \%$ (not considering the high values of 37 to $39 \mathrm{~mol} \%$ determined for Thermoanaerobacter ethanolicus by the buoyant density method), high $\mathrm{G}+\mathrm{C}$ composition ( 56 to $59 \mathrm{~mol} \%$ ) of genes coding for rRNA, lack of catalase and cytochromes, maximum growth temperature above $75^{\circ} \mathrm{C}$, optimal growth temperature above $65^{\circ} \mathrm{C}$, and a $\mathrm{pH}$ for growth between 5.5 and $8.5(1,5,10,13)$. In addition, Wiegel (14) pointed out that the only difference between Thermoanaerobacter ethanolicus and Thermobacteroides acetoethylicus is the inability of the latter species to form more than 1.5 mol of ethanol per mol of glucose utilized.

Description of Thermoanaerobacter acetoethylicus (Ben-Bassat and Zeikus) comb. nov. The description of the species has not been emended since its effective published description $(1,3)$. The transfer of the species to the genus Thermoanaerobacter does not change the description of this genus. The type strain of Thermoanaerobacter acetoethylicus is HTB2/W (ATCC 33265).

Description of the genus Coprothermobacter. The transfer of 
TABLE 1 . Characteristics differentiating $C$. proteolyticus from phylogenetically related and phenotypically similar taxa

\begin{tabular}{|c|c|c|c|c|c|c|c|}
\hline Bacterium(-a) & Morphology & Motility & $\begin{array}{l}\mathrm{mol} \% \\
\mathrm{G}+\mathrm{C}\end{array}$ & $\begin{array}{l}\text { Optimum } \\
\text { temp }\left({ }^{\circ} \mathrm{C}\right)\end{array}$ & $\begin{array}{l}\text { Maximum } \\
\text { temp }\left({ }^{\circ} \mathrm{C}\right)\end{array}$ & $\begin{array}{l}\text { Fermentation end } \\
\text { products }^{a}\end{array}$ & $\mathrm{~S}^{0}$ metabolism \\
\hline $\begin{array}{l}\text { Coprothermobacter proteo- } \\
\text { lyticus }\end{array}$ & Rods; pleomorph & - & 45 & 63 & 75 & $\mathrm{~A}, \mathrm{CO}_{2}, \mathrm{H}_{2}$ & $\mathrm{NR}^{b}$ \\
\hline Aquifex pyrophilus & Rods, aggregates & + & 40 & 85 & 95 & $-^{c}$ & $\mathrm{H}_{2} \mathrm{~S}$ from sulfur \\
\hline Thermotoga spp. & Rods, toga & $\operatorname{Var}^{d}$ & $40-46$ & $70-80$ & 90 & $\mathrm{~L}, \mathrm{~A}, \mathrm{CO}_{2}, \mathrm{H}_{2}$ & $\mathrm{H}_{2} \mathrm{~S}$ from sulfur \\
\hline Thermosipho spp. & Rods, toga, chains & - & 30 & 75 & 77 & $\mathrm{~L}, \mathrm{~A}, \mathrm{CO}_{2}, \mathrm{H}_{2}$ & $\mathrm{H}_{2} \mathrm{~S}$ from sulfur \\
\hline Fervidobacterium spp. & Rods, spheroids & Var & $34-40$ & 65 & 80 & $\mathrm{~L}, \mathrm{~A}, \mathrm{E}, \mathrm{b}, \mathrm{v}, \mathrm{CO}_{2}, \mathrm{H}_{2}$ & $\mathrm{H}_{2} \mathrm{~S}$ from sulfur \\
\hline Thermoanaerobacter spp. & Rods & Var & $31-37$ & $64-69$ & $75-78$ & $\mathrm{~A}, \mathrm{E}, \mathrm{L}, \mathrm{CO}_{2}, \mathrm{H}_{2}$ & $\mathrm{H}_{2} \mathrm{~S}$ from thiosulfate \\
\hline Thermoanaerobacterium spp. & Rods & + & $33-36$ & 60 & $68-75$ & $\mathrm{~A}, \mathrm{E}, \mathrm{L}, \mathrm{CO}_{2}, \mathrm{H}_{2}$ & $S^{0}$ from thiosulfate \\
\hline
\end{tabular}

${ }^{a}$ A, acetate; L, lactate; E, ethanol; b, $n$-butyrate; $\mathrm{v}, n$-valerate.

$b$ NR, not reported.

c - A. pyrophilus is chemolithoautotrophic.

${ }^{d}$ Var, variable.

the type species of the genus Thermobacteroides to the genus Thermoanaerobacter invalidates the genus Thermobacteroides (rule 37a [1]) (11). In order to find a place for the orphan Thermobacteroides proteolyticus, two options are available. One could revive the genus Thermobacteroides, or alternatively, a new genus could be proposed. The revival of Thermobacteroides, in our opinion, is unwise since the -bacteroides part of the name implies a relationship to the genus Bacteroides. As pointed out previously (8), Thermobacteroides proteolyticus is not a member of the Bacteroides-Cytophaga phylum but constitutes a deep-rooting phylum of the domain Bacteria. The origin of this species from a thermophilic digester fed with cattle manure and tannery waste led us to propose the genus name Coprothermobacter. This name appears to be appropriate, since the currently unavailable species Thermobacteroides leptospartum (12), which resembles Thermobacteroides proteolyticus in phenotypic properties and the base composition of DNA (Table 1), was also isolated from cattle manure. As long as Thermobacteroides leptospartum is unavailable, its phylogenetic position cannot be determined, and hence, this species cannot be reclassified at this time.

C. proteolyticus is proposed as the type species because its description (7) predates that of Thermobacteroides leptospartum $(4,12)$. Members of the genus Coprothermobacter can be distinguished from other anaerobic, thermophilic bacteria by a combination of characters (Table 1).

Description of Coprothermobacter Rainey and Stackebrandt gen. nov. Coprothermobacter (co' pro.ther'mo.bac'ter) gen. nov. Gr. fem. n. kopros manure; Gr. adj. thermos warm; Gr. hyp. mas. n. bakter rod; N.L. mas. n. Coprothermobacter, because it is a thermophilic rod-shaped bacterium isolated from cattle manure. The cellular characteristics have been adopted from the descriptions of Ollivier et al. (7) for Thermobacteroides proteolyticus. Gram-negative, nonmotile, non-spore-forming rods. Obligately anaerobic. Chemoorganotrophs which metabolize peptone and are proteolytic. Glucose and lactose are fermented; other carbohydrates are used poorly unless yeast extract and either rumen fluid or Trypticase peptone are added. The principal fermentation end products are acetic acid, $\mathrm{H}_{2}$, and $\mathrm{CO}_{2}$ or acetic acid and ethanol. Thermophilic temperature range for growth, with optimum of $65^{\circ} \mathrm{C}$. The $\mathrm{G}+\mathrm{C}$ content of the DNA is $45 \mathrm{~mol} \%$. The type species $C$. proteolyticus, represents a novel line of descent within the radiation of deepbranching phyla of the domain Bacteria.

The description of $C$. proteolyticus comb. nov. is as published for Thermobacteroides proteolyticus by Ollivier et al. (7).
We thank Thomas O. MacAdoo for his help in nomenclatural matters.

\section{REFERENCES}

1. Ben-Bassat, A., and J. G. Zeikus. 1981. Thermobacteroides acetoethylicus gen. nov. sp. nov., a new chemoorganotrophic, anaerobic, thermophilic bacterium. Arch. Microbiol. 128:365370 .

2. Cook, G. M., P. H. Janssen, and H. W. Morgan. 1991. Endospore formation by Thermoanaerobium brockii HTD4. Syst. Appl. Microbiol. 14:240-244.

3. International Journal of Systematic Bacteriology. 1983. Validation of the publication of new names and new combinations previously effectively published outside the IJSB. List no. 11. Int. J. Syst. Bacteriol. 33:672-674.

4. International Journal of Systematic Bacteriology. 1989. Validation of the publication of new names and new combinations previously effectively published outside the IJSB. List no. 28. Int. J. Syst. Bacteriol. 39:93-94.

5. Jain, M. K., and J. G. Zeikus. 1992. The genera Thermoanaerobacter, Thermoanaerobium, and other thermoanaerobic saccharolytic bacteria of uncertain taxonomic affiliation, p. 19011913. In A. Ballows, H. G. Trüper, M. Dworkin, W. Harder, and K.-H. Schleifer (ed.), The prokaryotes, 2nd ed. SpringerVerlag, New York.

6. Lee, Y. E., M. K. Jain, C. Lee, S. E. Lowe, and J. G. Zeikus. 1993. Taxonomic distinction of saccharolytic thermophilic anaerobes: description of Thermoanaerobacterium xylanolyticum gen. nov., sp. nov., and Thermoanaerobacterium saccharolyticum gen. nov., sp. nov.; reclassification of Thermoanaerobium brockii, Clostridium thermosulfurogenes, and Clostridium thermohydrosulfuricum E100-69 as Thermoanaerobacter brockii comb. nov., Thermoanaerobacterium thermosulfurigenes comb. nov., and Thermoanaerobacter thermohydrosulfuricus comb. nov., respectively; and transfer of Clostridium thermohydrosulfuricum $39 \mathrm{E}$ to Thermoanaerobacter ethanolicus. Int. J. Syst. Bacteriol. 43:41-51.

7. Ollivier, B. M., R. A. Mah, T. J. Ferguson, D. R. Boone, J. L. Garcia, and R. Robinson. 1985. Emendation of the genus Thermobacteroides. Thermobacteroides proteolyticus sp. nov., a proteolytic acetogen from a methanogenic enrichment. Int. J. Syst. Bacteriol. 35:425-428.

8. Rainey, F. A., and E. Stackebrandt. 1993. Phylogenetic analysis of the bacterial genus Thermobacteroides indicates an ancient origin of Thermobacteroides proteolyticus. Lett. Appl. Microbiol. 16:282-286

9. Rainey, F. A., N. L. Ward, H. W. Morgan, R. Toalster, and E. Stackebrandt. 1993. Phylogenetic analysis of anaerobic thermophilic bacteria: aid for their reclassification. J. Bacteriol. 175: 4772-4779.

10. Schmid, U., H. Giesel, and H. Sahm. 1986. Thermoanaerobacter finnii spec. nov., a new ethanologenic sporogenous bacterium. Syst. Appl. Microbiol. 8:80-85.

11. Sneath, P. H. A. (ed.). 1992. International code of nomenclature 
of bacteria (1990 revision). American Society for Microbiology, Washington, D.C.

12. Toda, Y., T. Saiki, T. Uozumi, and T. Beppu. 1988. Isolation and characterization of a protease-producing, thermophilic, anaerobic bacterium, Thermobacteroides leptospartum sp. nov. Agric. Biol. Chem. 52:1339-1344.

13. Wiegel, J., and L. G. Ljungdahl. 1981. Thermoanaerobacter ethanolicus gen. nov., spec. nov., a new, extreme thermophilic, anaerobic bacterium. Arch. Microbiol. 128:343-348.

14. Wiegel, J. K. W. 1986. Genus Thermoanaerobacter Wiegel and Ljungdahl, 1982, 384 ${ }^{\mathrm{VP}}$ (effective publication Wiegel and Ljungdahl 1981, 348), p. 1379-1383. In P. H. A. Sneath, N. S. Mair, M. E. Sharpe, and J. G. Holt (ed.), Bergey's manual of systematic bacteriology, vol. 2. Williams \& Wilkins Co., Baltimore. 